\title{
GSL Müzik Bölümleri Müfredatındaki Türk ve Batı Müziği Derslerine Yönelik Tutum Ölçeği Geliştirme Çalışması*
}

\section{Attitude Scale Development Study for Turkish and Classical Music Courses in the Curriculum of Fine Arts High School Music Departments}

\author{
Merve Karakuş \\ Müzik Öğretmeni, Erzurum Karaçoban İlçesi Mareşal Fevzi Çakmak Ortaokulu \\ email: mervedastann@gmail.com (DORCID ID: https://orcid.org/0000-0002-2360-5139
}

\section{Koray Çelenk}

Dr. Öğr. Üyesi, Atatürk Üniversitesi Güzel Sanatlar Fakültesi Müzik Bilimleri Bölümü

email: koraycelenk@atauni.edu.tr (DORCID ID: https://orcid.org/0000-0002-0580-2489 *Bu çalışma “Güzel Sanatlar Lisesi Müzik Bölümü Öğrencilerinin Türk Müziği ve Batı Müziği Derslerine Yönelik Tutumları
Üzerine Bir İnceleme” isimli yüksek lisans tezinden türetilmiştir.

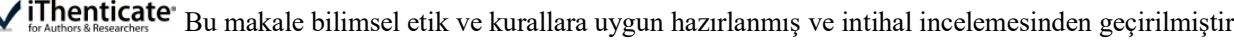

Atıf (APA 6)/To cite this article

Karakuş, M., \& Çelenk, K. (2020). GSL müzik bölümleri müfredatındaki Türk ve Batı Müziği derslerine yönelik öğrenci tutum ölçeği geliştirme çalışması. Atatürk Üniversitesi Güzel Sanatlar Enstitüsü Dergisi, 26(Müzik Özel Sayıs1), 327-337. doi: https://doi.org/10.35247/ataunigsed.701526

Makale Gönderim Tarihi/Received: 10/12/2019

Makale Kabul Tarihi/Accepted: 12/03/2020

Makale Yayın Tarihi/Published: 25/03/2020

Research Article / Araştırma Makalesi

Öz

Araştırmanın amacı, Milli Eğitim Bakanlığı Talim ve Terbiye Kurulu Baskanlığı'nın 60 sayı ve 19/02/2018 tarihli kararı ile 2018-2019 eğitim-öğretim yllından itibaren uygulanmaya başlanan Güzel Sanatlar Liseleri (GSL) Müzik Bölümleri müfredatındaki Türk Müziği ve Batı Müziği derslerine yönelik öğrenci tutumlarını belirlemek için bir tutum ölçeği geliştirmektir. Araştırma, nitel destekli olup, nicel verilere bağlı betimsel araştırma yöntemlerinden tarama (survey) modelinde tasarlanmış ve veri toplama aracı olarak araştırmacılar tarafindan geliştirilen tutum ölçeği kullanılmıștır.

Araştırmanın çalışma grubunu 2018-2019 eğitim-öğretim yılında Erzurum GSL, Aksaray GSL, Mamak Mimar Sinan GSL, Mersin Nevit Kodallı GSL, Gaziantep Ticaret Odası GSL ve Buca Ișlay Saygın GSL'de öğrenim gören 151 öğrenci oluşturmaktadır

Araștırmada literatürdeki tutum ölçekleri incelenmiş ve GSL müfredatındaki Türk ve Batı Müziği derslerine yönelik aynı tutum ifadelerini içeren, ancak birbirinden bağımsız ve 20 maddeden oluşan iki tutum ölçeği geliștirilmiștir. Ölçeklerdeki maddeler hem olumlu hem de olumsuz ifadeleri içermektedir. Ölçeklerin geçerliği için her iki ölçekteki 26 madde uzman görüşüne sunulmus, maddelerin kapsam gecerlik oranı (KGO), kapsam geçerlik ölçütü (KGÖ) ve kapsam geçerlik indeksi elde edilerek kapsam gecerliği ortaya koyulmaya calıșılmıștır. Ölceklerin yapı geçerliğini tespit etmek amacıyla faktör analizi yapılmış, ölçeklerin tek faktörlü bir yapıya sahip oldukları ve yapı geçerliğini sağladıkları belirlenmiştir. Ölçeklerin güvenirliği için ise, Cronbach's Alpha güvenirlik analizi uygulanmış ve güvenirlik katsayıları $\alpha=0.962$ ve $\alpha=965$ olarak tespit edilmis ve ölçeğin yüksek derecede güvenilir olduğu sonucuna ulaşılmıştır. Geliştirilen ölçeklerin, Güzel Sanatlar Liseleri müfredatındaki Türk Müziği ve Batı Müziği derslerine yönelik öğrenci tutumlarını belirlemek amacıyla kullanılabilecek geçerli ve güvenilir birer ölçme aracı oldukları söylenebilir.

Anahtar kelimeler: GSL, Türk Müziği, Batı Müziği, Tutum Ölçeği

\begin{abstract}
The aim of the study is to develop an attitude scale to determine student attitudes towards Turkish Music and Classical Music courses in the Fine Arts High Schools (GSL) Music Departments curriculum which implemented numbered 60 and dated February 19, 2018 decision of the Ministry of National Education Board of Education and Discipline since 2018-2019 academic year. The study was designed as a survey model which is one of the descriptive research methods based on quantitative data, and the attitude scale developed by the researcher based on the literature survey was used as a data collection tool.
\end{abstract}

The study group consists of 151 students who is studying in Erzurum Fine Arts High School, Aksaray Fine Arts High School, Mamak Mimar Sinan Fine Arts High School, Mersin Nevit Kodallı Fine Arts High School, Gaziantep Ticaret Odası Fine Arts High School, and Buca Ișılay Saygın Fine Arts High School in 2018-2019 academic year.

In the study, attitude scales in the literature were examined and two attitude scales towards Turkish and Classical Music courses in the curriculum of Fine Arts High School, which include the same attitude expressions, but are independent from each other and consisting of 20 items were developed. Items in the scales contain both positive and negative expressions. For the validity of the scales, 26 items of both scales were presented to the expert opinion, and the content validity index (CVI), scope validity criterion (SVC) and scope validity index were obtained and the content validity was tried to be determined. Factor analysis was performed to determine the construct validity of the scales, and it was determined that the scales had a single-factor structure and provided the construct validity. For the reliability of the scales, Cronbach's Alpha reliability analysis was applied and the reliability coefficients were determined as $\alpha=0.962$ and $\alpha=965$ and it was concluded that the scale was highly reliable. It can be said that the developed scales are valid and reliable measurement tools that can be used to determine student attitudes towards Turkish Music and Classical Music courses in the curriculum of Fine Arts High School

Keywords: Fine Arts High School, Turkish Music, Classical Music, Attitude Scale 


\section{Giriș}

Müzik Eğitimi ülkemizde Genel ya da Örgün Müzik Eğitimi, Amatör ya da Özengen Müzik Eğitimi ve Mesleksel ya da Profesyonel Müzik Eğitimi olmak üzere üç ana başlığı kapsamaktadır. Genel Müzik Eğitimi, zorunlu veya seçmeli-zorunlu olmak üzere anaokulu, ilkokul, ortaokul ve lise kademelerini kapsayacak şekilde, bu kademelerde öğrenim gören bireylere, Milli Eğitim Müzik Dersi Müfredat Programları çerçevesinde ortak ve genel kültürün en önemli öğesi olan müzik ile ilgili temel bilgi ve beceriyi kazandırmayı amaçlayan müzik eğitimini; Amatör ya da Özengen Müzik Eğitimi, birey ayırımı yapmaksızın zorunlu olarak değil bireyin ilgi, istek ve gönüllülük anlayışına bağlı olarak ve müziği maddi bir karşılık beklemeksizin hobi anlayışıyla yapmak isteyen bireylere müzik kurslarında, halk eğitim merkezlerinde, derneklerde, kulüp faaliyetlerinde v.b. yapılanmalarda verilen müzik eğitimini; Mesleksel ya da Profesyonel Müzik Eğitimi ise, Milli Eğitim'in Yükseköğretim basamağını oluşturan Müzik Üniversitesi, Konservatuarlar'ın Müzik ile ilgili bölümleri, Eğitim Fakülteleri Müzik Eğitimi Anabilim Dalları, Güzel Sanatlar Fakülteleri'nin Müzik ile ilgili bölümleri ve Müzik ve Sahne Sanatları Fakülteleri’nin Müzik ile ilgili bölümlerini kapsayacak şekilde, müziğin mesleki açıdan eğitimsel, sanatsal ve bilimsel başlıklarını kapsayan (Müzik öğretmenliği, Müzik Teknologluğu, İcracılık, Bestecilik, Müzik Bilimciliği v.b.) kol veya dalları meslek edinmeyi amaçlayan ve müziğe bu kol ve dalların gerektirdiği temel yeterlilik düzeyinde yeteneği olan bireylere mesleki bilgi ve beceriyi kazandırmayı amaçlayan müzik eğitimini ifade etmektedir. Milli Eğitim'in Ortaöğretim basamağını oluşturan Güzel Sanatlar Liseleri Müzik Bölümleri ise Genel Müzik Eğitimi başlığı altında olması gerektiği düşünülse de, Mesleksel Müzik Eğitimi Kurumları'nın alt yapısı ya da hazırlayıcısı niteliği olan ve Mesleki Müzik Eğitimi ile ilişkilendirilebilecek bir görünüm sergilemektedir (Çelenk ve Özşen, 2018 , s. 494).

İlk kez 1989-1990 eğitim-öğretim yılında açılan Güzel Sanatlar liseleri, ortaöğretimin genel amaçlarının yanı sıra, öğrencilere güzel sanatlarla ilgili temel bilgi ve beceriler kazandırmayı ve güzel sanatlar alanında nitelikli insan yetiştirilmesine kaynaklık etmeyi amaçlamaktadır. Güzel Sanatlar liselerinde; Görsel Sanatlar alanının yanı sıra "Müzik, Türk Halk Müziği ve Türk Sanat Müziği” alanları bulunmaktadır (MEB, 2018).

Türk ve Batı Müziğine yönelik teorik ve uygulamalı dersler, Güzel Sanatlar Liseleri müfredatının temel öğelerini oluşturmaktadır. Bu temel öğelere karşı öğrencilerin geliştirmiş oldukları tutumların belirlenmesi, eğitim-öğretim süreçlerinde yaşanan sorunları belirlemek ve oluşturulacak müfredatların daha sağlam temellere dayandırılarak oluşturulmasında önemli katkılar sağlamaktadır.

Eğitim sürecinin önemli bir öğesi olan tutum, öğrenmenin gerçekleşmesinde etkilidir. Öğrencilerin okula, öğretmene, derse yönelik tutumları ile onların akademik başarıları, eğitim programlarının hedeflerine ulaşma düzeyleri arasında güçlü ilişkiler olduğunu ortaya koyan araştırmalar bulunmaktadır. Söz konusu araştırma bulgularına göre, öğrencilerin öğrenmeye ve derse yönelik tutumlarının olumlu olması onların akademik başarılarını artırmaktadır. Nitekim tutumlar ile başarılar arasındaki anlamlı düzeydeki ilişkiler, tutumların bilişsel alan davranışları kadar önemli olduğunu göstermektedir (Berberoğlu, 1990; Saracaloğlu, 1996'dan aktaran Şen ve Şentürk, 2015, s. 263).

Bir ölçme aracı olan tutum öznel ve kişiye özgüdür. Tutum kelime anlamı olarak herhangi bir kimsenin bir nesneye ya da bir duruma olumlu veya olumsuz davranış gösterme eğilimidir. Tutum, bireyin kendine ya da çevresindeki herhangi bir nesne, toplumsal konu, ya da olaya karşı deneyim, bilgi, duygu ve güdülerine (motivasyon) dayanarak örgütlediği zihinsel, duygusal ve davranışsal bir tepki ön eğilimidir (İnceoğlu, 2010, s. 13).

Tutumun oluşmasında çeşitli etkenler vardır. Oskamp (1977), bireyin tutum geliştirmesinde rol oynayan etkenleri, ailenin etkisi, çevrenin etkisi ve kişisel deneyimlerin etkisi olarak üç gruba ayırmıştır.

Canakay (2006)'a göre, tutumlar değişebilir ya da değiştirilebilir. Buna göre, olumsuz tutum olumlu, olumlu tutum ise olumsuz tutuma dönüşebilmektedir. Tutumların, düşünce ve davranışlara temel oluşturduğu, yönlendirdiği dikkate alındığında, bireyin başarıya yönlenmesinde olumlu tutum geliştirmenin gerekliliği göze çarpmaktadır.

Bir durum ya da nesneye karşı gözlenen ya da ölçülen tutumlar, olumlu ya da olumsuz yönde değiştirilebildiğine göre, öğrencilerin derslere karşı gösterdikleri tutumların ölçülmesi, olumsuz tutum gösterdikleri derslerin belirlenmesi ve bu derslere karşı tutumlarının istendik yönde değiştirilmesinin, daha önceden belirtildiği gibi öğrencilerin akademik başarılarını olumlu yönde etkileyeceği düşünülmektedir.

Tutum ölçmede araştırmaya konu olan nesneye yönelik cümle ve ifadeler oluşturulmaktadır. Oluşturulan bu cümle ve ifadelere, ölçüm yapılacak gruptaki bireylerin gerçek duygularını yansıtacak şekilde tepkide bulunmaları istenmektedir. Bu cümle ya da ifadeler listesine ise ölçek denilmektedir. Aslında tutum ölçekleri, bireyin iç dünyasını ortaya çıkaran anketlerdir. Yapılan ölçüm sonucunda bireyin duygu yoğunluğunun, araştırmaya konu olan nesnenin lehinde ya da aleyhinde olma durumu ortaya koyulmaktadır (Tavşancıl, 2006, s. 106). 
Karasar’a (2007) göre, tutum ölçme "çok sorulu” bir yaklaşımı gerektirmektedir. Likert ve Thurston buna örnek olarak verilebilir. Thurstone, Gutman, Bogardus ve Likert gibi tutum ölçeği geliştirme yaklaşımları geliştirilmiş olmakla beraber bu ölçeklerden en çok kullanılanı Likert derecelendirme ölçeğidir (s. 182-184).

Likert tipi sorular, araştırılan konu hakkında tutum veya görüş içeren bir ifade ve bu ifadeye katılım düzeyini belirten seçenekler içerir. Likert tipi sorularda katılım düzeyini belirlemek amacıyla iki aşırı uç arasında yer alan birden çok seçenek sunulur. Bu seçenekler "en yüksekten en düşüğe" veya "en iyiden en kötüye" doğru dereceli bir şekilde sıralanır. Analiz aşamasında bu seçenekler derecelerine göre birer sayısal değer atanarak kodlanır ve böylece nitel veri nicel veriye dönüştürülerek analiz edilir. Ölçeklerden çıkan sonuçlar tutum puanlarına göre aritmetik ortalama, standart kayma, ölçeğin güvenirliği gibi istatistiklerle hesaplanabilir (Turan, Şimşek, \& Aslan, 2015, s. 188).

Bu doğrultuda araştırmada, Milli Eğitim Bakanlığı Talim ve Terbiye Kurulu Başkanlığı'nın 60 sayı ve 19/02/2018 tarihli kararı ile 2018-2019 eğitim-öğretim yılından itibaren uygulanmaya başlanan Güzel Sanatlar Liseleri (GSL) Müzik Bölümleri müfredatındaki Türk Müziği ve Batı Müziğine yönelik derslere karşı öğrencilerin tutumlarını ölçmeye yönelik birer tutum ölçeği geliştirmek ve konuyla ilgili gelecekteki çalışmalara 1şık tutabilmek amaçlanmıştır. Bu amaca bağlı olarak cevap aranan araştırma soruları şu şekildedir:

1. GSL Türk Müziği ve Batı Müziği derslerine yönelik oluşturulan tutum ölçekleri kapsam geçerliğini sağlamakta midir?

2. GSL Türk Müziği ve Batı Müziği derslerine yönelik oluşturulan tutum ölçekleri yapı geçerliğini sağlamakta midir?

3. GSL Türk Müziği ve Batı Müziği derslerine yönelik oluşturulan tutum ölçekleri güvenirliği sağlamakta mıdır?

\section{Yöntem}

$\mathrm{Bu}$ araştırma nitel destekli olup, nicel verilere bağlı betimsel araştırma yöntemlerinden tarama (survey) modelinde tasarlanmıştır. Araştırmanın çalışma grubunu, Erzurum GSL, Aksaray GSL, Mamak Mimar Sinan GSL, Mersin Nevit Kodallı GSL, Gaziantep Ticaret Odası GSL ve Buca Işılay Saygın GSL müzik bölümü öğrencilerinden seçilen 151 öğrenci oluşturmaktadır. Çalışma grubunun demografik özellikleri Tablo 2'de verilmiştir.

Tablo 1

Araştırmanın çalışma grubuna ait demografik özellikler

\begin{tabular}{lcc}
\hline Araştırmanın Gerçekleștirildiği Liseler & f & $\mathbf{\%}$ \\
\hline Erzurum Güzel Sanatlar Lisesi & 27 & 19.2 \\
Aksaray Güzel Sanatlar Lisesi & 24 & 12.1 \\
Mamak Mimar Sinan Güzel Sanatlar Lisesi & 24 & 19.9 \\
Mersin Nevit Kodallı Güzel Sanatlar Lisesi & 26 & 17.9 \\
Gaziantep Ticaret Odası Güzel Sanatlar Lisesi & 26 & 16.1 \\
Buca Ișlay Saygın Güzel Sanatlar Lisesi & 24 & 14.8 \\
Toplam & $\mathbf{1 5 1}$ & $\mathbf{1 0 0 . 0}$ \\
\hline Sınıf Düzeyi & $\mathbf{f}$ & $\mathbf{\%}$ \\
\hline 9. Sınıf & 37 & 32.6 \\
10. Sınıf & 38 & 28.4 \\
11.Sınıf & 37 & 24.0 \\
12.Sınıf & 39 & 15.0 \\
Toplam & $\mathbf{1 5 1}$ & $\mathbf{1 0 0 . 0}$ \\
\hline Cinsiyet & $\mathbf{f}$ & $\mathbf{\%}$ \\
\hline Erkek & 77 & 50.2 \\
Kız & 74 & 49.8 \\
Toplam & $\mathbf{1 5 1}$ & $\mathbf{1 0 0 . 0}$ \\
\hline
\end{tabular}

Araştırmada literatür taraması yapılarak var olan tutum ölçekleri incelenmiş ve bu doğrultuda araştırmanın amacına uygun olarak Türk ve Batı müziği için birer tutum ölçeği geliştirilmeye çalışılmıştır. Her iki tutum ölçeği için, Türk müziği ve Batı müziği ifadeleri ayrı, ancak tutum ifadeleri aynı olan ve 26 maddeden oluşan bir madde havuzu oluşturulmuş ve oluşturulan maddeler kapsam geçerliği için uzman görüşüne sunulmuştur. Görüşleri alınan uzman grubunun bilgileri Tablo 2'de gösterilmiştir.

Tablo 2

Uzman Grubu Bilgileri

\begin{tabular}{lccc}
\hline & Üniversite/Fakülte/Bölüm & Ünvan & Alan \\
\hline 1 & Atatürk Üniversitesi K.K. Eğitim Fakültesi Müzik Eğitimi Ana Bilim Dalı & Doç. Dr. & Müzik Eğitimi \\
2 & Atatürk Üniversitesi K.K. Eğitim Fakültesi Müzik Eğitimi Ana Bilim Dalı & Doç. Dr. \\
3 & Atatürk Üniversitesi K. K. Eğitim Fakültesi Eğitim Bilimleri Bölümü & Dr. Öğr. Ü. & Müzik Eğitimi \\
4 & Atatürk Üniversitesi Güzel Sanatlar Fakültesi Müzik Bilimleri Bölümü & Doç. Dr. & Müzik Eğgitimi \\
5 & Atatürk Üniversitesi Güzel Sanatlar Fakültesi Müzik Bilimleri Bölümü & Dr. Öğr. Ü. & Müzik Eğitimi \\
\hline
\end{tabular}


Veriler uzman görüşü alındıktan sonra nihai halini alan ölçeklerin çalışma grubuna uygulanması sonucunda elde edilmiştir. Elde edilen verilerin analizinde ölçeklerin kapsam geçerliğini sağlayıp sağlamadığı ve ölçeklerde kalacak maddelerin tespiti için KGO (Kapsam Geçerlik Oranı) ve KGİ (Kapsam Geçerlik İndeksi) değerleri belirlenmiştir. Kapsam geçerlik oranları, Lawshe (1975) tarafindan geliştirilen 6 aşamalı Lawshe tekniği kullanılarak belirlenmiştir. Lawshe tekniğine göre, en az 5 en fazla 40 uzman görüşü alınarak, her madde "madde hedeflenen yapıyı ölçüyor", "madde yapı ile ilişkili ancak gereksiz" ve "madde hedeflenen yapıyı ölçmüyor" şeklinde derecelendirilmektedir. KGO hesaplamasında $K G O=N_{G} /(N / 2)$ - 1 formülü kullanılmaktadır. Burada; $\mathrm{N}_{\mathrm{G}}$, maddeye gerekli diyen uzmanların sayısını ve $\mathrm{N}$ maddeye ilişkin görüş belirten toplam uzman sayısını göstermektedir. KGO değerleri negatif ya da 0 (sıfır) içeren maddeler elenir. KGO değerleri pozitif olan maddeler için ise, .05 anlamlılık düzeyinde KGO'ların minimum değerleri (kapsam geçerlik ölçütü) Veneziano ve Hooper (1997) tarafından oluşturulan tabloya göre değerlendirilir. Buna göre, uzman sayısına ilişkin minimum değerler aynı zamanda maddenin istatistiksel anlamlılığını belirlemektedir. Tablo 3'de, kapsam geçerliğinin sağlanmasında ve elde edilen KGO değerlerinin karşılaştırılmasında kullanılan KGÖ (Kapsam Geçerlik Ölçütü) değerleri görülmektedir.

Tablo 3

KGO Karşılaştırması İçin Minimum Değerler

\begin{tabular}{ccc}
\hline Uzman Sayıs & KGÖ \\
\hline 5 & 0.99 & 0.99 \\
6 & 0.99 & 0.78 \\
7 & 0.75 & 0.62 \\
8 & 0.59 & 0.56 \\
9 & 0.54 \\
10 & 0.51 \\
11 & 0.49 \\
12 & 0.42 \\
13 & 0.37 \\
14 & 0.33 \\
15 & 0.31 \\
20 & 0.29 \\
\hline
\end{tabular}

Yeşilyurt ve Çapraz (2018)'a göre, elde edilen KGO değeri, uzman sayısına göre verilen KGÖ değerinden büyükse kapsam geçerliği sağlanmış, küçükse sağlanmamış demektir. Ayrıca, elde edilen KGİ değeri KGÖ değerinden büyükse, ölçekte kalan maddeler kapsam geçerliğini sağlamış; elde edilen KGİ değeri KGÖ değerinden küçükse kalan maddeler kapsam geçerliğini sağlamamış anlamına gelmektedir.

Ölçeklerin yapı geçerliğine yönelik olarak faktör analizi uygunluğu için Kaiser-Meyer-Olkin (KMO) katsayısı ve Barlett Sphericity testi ve doğrulayıcı faktör analizi uygulanmıştır. Büyüköztürk (2011)'e göre, maddelerin faktörleştirilebilir olması için KMO'nun 0.60 değerinden yüksek çıkması ve Barlett testi sonucu hesaplanan ki kare değerinin .05 düzeyinde anlamlı çıkması gerekmektedir. Faktör analizinde, başlangıç özdeğerleri 1'den büyük değerler faktörleri oluşturmaktadır. Ortak varyanslarda ise 0.40 'dan büyük değerler madde kalitesini ve ölçeğe ilişkin varyansın açıklandığını göstermektedir. (aktaran Çelenk, 2019, s. 121).

Türk ve Batı müziği derslerine yönelik tutum ölçeklerinin güvenirliğini test etmek için ise, Cronbach's Alpha güvenirlik testi uygulanmıştır. Özdamar (2011), güvenirlik katsayısında kıstas alınacak değerleri

“ $0.00<\alpha<0.40$ ise ölçek güvenilir değildir.

$0.40<\alpha<0.60$ ise ölçek düşük güvenirliktedir.

$0.60<\alpha<0.80$ ise oldukça güvenilirdir.

$0.80<\alpha<1.00$ ise ölçek yüksek derecede güvenilirdir" şeklinde tanımlamıştır (s. 605).

\section{Bulgular}

\section{1. Ölçeklerin kapsam geçerliklerine yönelik bulgular}

İki ölçek için oluşturulan 26 madde, uygun, düzeltilmeli ve uygun değil seçeneklerini içeren bir formla birlikte uzman görüşüne sunulmuştur. Uzman görüşleri alındıktan sonra ölçeklerin kapsam geçerliğini sağlayıp sağlamadığı ve ölçeklerde kalacak maddelerin tespiti için KGO (Kapsam Geçerlik Oranı) ve KGİ (Kapsam Geçerlik İndeksi) değerleri belirlenmiştir. KGİ hesaplaması ise uygun görülen maddelerin KGO değerlerinin ortalaması hesaplanarak elde edilmiştir. KGO, KGÖ ve KGİ değerleri Tablo 4'de verilmiştir. 
Merve Karakuş, Koray Çelenk

GSL Müzik Bölümleri Müfredatındaki Türk ve Batı Müziği Derslerine Yönelik Tutum Ölçeği Geliştirme Çalışması

GSED, 2020; Cilt: 26, Sayı: Müzik Özel Sayısı: 327-337 - DOI: 10.32547/ataunigsed.701526

Tablo 4

Türk ve Batı Müziği dersleri ölçek maddeleri KGO, KGÖ ve KGİ değerleri

\begin{tabular}{|c|c|c|c|c|c|c|c|c|c|}
\hline \multicolumn{10}{|c|}{ Türk Müziği Derslerine Yönelik Maddeler } \\
\hline Madde & Uygun & Düzeltilmeli & $\begin{array}{c}\text { Uygun } \\
\text { Değil }\end{array}$ & KGO & Madde & Uygun & Düzeltilmeli & $\begin{array}{c}\text { Uygun } \\
\text { Değil }\end{array}$ & KGO \\
\hline 1 & 5 & 0 & 0 & 1.00 & 14 & 5 & 0 & 0 & 1.00 \\
\hline 2 & 5 & 0 & 0 & 1.00 & 15 & 5 & 0 & 0 & 1.00 \\
\hline 3 & 5 & 0 & 0 & 1.00 & 16 & 5 & 0 & 0 & 1.00 \\
\hline 4 & 5 & 0 & 0 & 1.00 & 17 & 5 & 0 & 0 & 1.00 \\
\hline 5 & 5 & 0 & 0 & 1.00 & 18 & 1 & 0 & 5 & -0.60 \\
\hline 6 & 5 & 0 & 0 & 1.00 & 19 & 2 & 0 & 4 & -0.20 \\
\hline 7 & 5 & 0 & 0 & 1.00 & 20 & 2 & 0 & 4 & -0.20 \\
\hline 8 & 5 & 0 & 0 & 1.00 & 21 & 1 & 0 & 5 & -0.60 \\
\hline 9 & 5 & 0 & 0 & 1.00 & 22 & 1 & 0 & 5 & -0.60 \\
\hline 10 & 5 & 0 & 0 & 1.00 & 23 & 5 & 0 & 0 & 1.00 \\
\hline 11 & 5 & 0 & 0 & 1.00 & 24 & 5 & 0 & 0 & 1.00 \\
\hline 12 & 5 & 0 & 0 & 1.00 & 25 & 5 & 0 & 0 & 1.00 \\
\hline 13 & 5 & 0 & 0 & 1.00 & 26 & 1 & 0 & 5 & -0.60 \\
\hline \multicolumn{5}{|c|}{ Toplam Uzman Sayısı } & \multicolumn{5}{|c|}{5} \\
\hline \multicolumn{5}{|c|}{ Kapsam Geçerlik Ölçütü (KGÖ) } & \multicolumn{5}{|c|}{0.99} \\
\hline \multicolumn{5}{|c|}{ Kapsam Geçerlik İndeksi (KGI) } & \multicolumn{5}{|c|}{1.000} \\
\hline \multicolumn{10}{|c|}{ Batı Müziği Derslerine Yönelik Maddeler } \\
\hline Madde & Uygun & Düzeltilmeli & $\begin{array}{c}\text { Uygun } \\
\text { Değil }\end{array}$ & KGO & Madde & Uygun & Düzeltilmeli & $\begin{array}{c}\text { Uygun } \\
\text { Değil }\end{array}$ & KGO \\
\hline 1 & 5 & 0 & 0 & 1.00 & 14 & 5 & 0 & 0 & 1.00 \\
\hline 2 & 5 & 0 & 0 & 1.00 & 15 & 5 & 0 & 0 & 1.00 \\
\hline 3 & 5 & 0 & 0 & 1.00 & 16 & 5 & 0 & 0 & 1.00 \\
\hline 4 & 5 & 0 & 0 & 1.00 & 17 & 5 & 0 & 0 & 1.00 \\
\hline 5 & 5 & 0 & 0 & 1.00 & 18 & 1 & 0 & 5 & -0.60 \\
\hline 6 & 5 & 0 & 0 & 1.00 & 19 & 2 & 0 & 4 & -0.20 \\
\hline 7 & 5 & 0 & 0 & 1.00 & 20 & 2 & 0 & 4 & -0.20 \\
\hline 8 & 5 & 0 & 0 & 1.00 & 21 & 1 & 0 & 5 & -0.60 \\
\hline 9 & 5 & 0 & 0 & 1.00 & 22 & 1 & 0 & 5 & -0.60 \\
\hline 10 & 5 & 0 & 0 & 1.00 & 23 & 5 & 0 & 0 & 1.00 \\
\hline 11 & 5 & 0 & 0 & 1.00 & 24 & 5 & 0 & 0 & 1.00 \\
\hline 12 & 5 & 0 & 0 & 1.00 & 25 & 5 & 0 & 0 & 1.00 \\
\hline 13 & 5 & 0 & 0 & 1.00 & 26 & 1 & 0 & 5 & -0.60 \\
\hline \multicolumn{5}{|c|}{ Toplam Uzman Sayısı } & \multicolumn{5}{|c|}{5} \\
\hline \multicolumn{5}{|c|}{ Kapsam Geçerlik Ölçütü (KGÖ) } & \multicolumn{5}{|c|}{0.99} \\
\hline \multicolumn{5}{|c|}{ Kapsam Geçerlik İndeksi (KGI) } & \multicolumn{5}{|c|}{1.000} \\
\hline
\end{tabular}

Tablo 4'de KGO, KGÖ ve KGİ değerlerine bakıldığında, KGO değeri KGÖ değerinden büyük 20 maddenin kaldığı ve KGİ (1.00) > KGÖ (0.99) olduğu için Türk ve Batı Müziği tutum ölçeklerinde kalan 20 maddenin kapsam geçerliğini sağladığı söylenebilir.

\section{2. Ölçeklerin yapı geçerliklerine yönelik bulgular}

Kapsam geçerliğini sağlayan 20'şer maddelik tutum ölçekleri, yapı geçerliğinin de sağlandığını ortaya koymak amacıyla, öncelikle Kaiser-Meyer-Olkin (KMO) ve Barlett Sphericity testine tabi tutulmuştur. Test sonuçları Tablo 5'de görülmektedir.

Tablo 5

Faktör analizi uygunluğu KMO ve Barlett testi sonuçları

\begin{tabular}{|c|c|c|}
\hline \multicolumn{3}{|c|}{ Türk Müziği Derslerine Yönelik Maddeler } \\
\hline Kaiser-Meyer-Olkin Örnekleme Yeterliğ & & .966 \\
\hline \multirow{3}{*}{ Bartlett's Sphericity Testi } & $\chi^{2}$ & 6691.740 \\
\hline & Sd & 190 \\
\hline & $\mathbf{p}$ & .000 \\
\hline \multicolumn{3}{|c|}{ Batı Müziği Derslerine Yönelik Maddeler } \\
\hline \multicolumn{2}{|c|}{ Kaiser-Meyer-Olkin Örnekleme Yeterliği Ölçümü } & .962 \\
\hline \multirow{3}{*}{ Bartlett's Sphericity Testi } & $\chi^{2}$ & 6793.336 \\
\hline & Sd & 190 \\
\hline & p & .000 \\
\hline
\end{tabular}

Tablo 5'e göre, hem Türk Müziği, hem de Batı Müziği derslerine yönelik maddelerin KMO değerinin 0.60'dan yüksek çıkması $\left(\mathrm{KMO}_{\mathrm{TM}}=0.966>0.60, \mathrm{KMO}_{\mathrm{BM}}=0.962>0.60\right)$ ve Barlett testi sonucu hesaplanan ki kare değerinin .05 düzeyinde anlamlı çıkması $\left(\mathrm{TM} \chi^{2}{ }_{190}=6691.740, p<.05, \mathrm{BM} \chi^{2}{ }_{190}=6793.336, p<.05\right)$ maddelerin 
Merve Karakuş, Koray Çelenk

GSL Müzik Bölümleri Müfredatındaki Türk ve Batı Müziği Derslerine Yönelik Tutum Ölçeği Geliștirme Çalıșması

GSED, 2020; Cilt: 26, Say1: Müzik Özel Sayıs1: 327-337 - DOI: 10.32547/ataunigsed.701526

faktörleştirilebilir ve faktör analizine uygun olduğunu göstermektedir. Tablo 6'da Türk ve Batı Müziği derslerine yönelik maddeler için yapılan doğrulayıcı ve açımlayıcı faktör analizi sonuçları görülmektedir.

Tablo 6

Faktör analizi toplam varyans açıklaması tablosu

\begin{tabular}{|c|c|c|c|c|c|c|c|c|c|}
\hline \multicolumn{10}{|c|}{ Türk Müziği Derslerine Yönelik Maddeler } \\
\hline \multirow[t]{2}{*}{ Madde } & \multicolumn{3}{|c|}{ Başlangıç Özdeğerleri } & \multicolumn{3}{|c|}{ Kareli Yüklerin Ağırlıklı Toplamları } & \multicolumn{3}{|c|}{$\begin{array}{c}\text { Kareli Yüklerin } \\
\text { DöndürülmüsșToplamları }\end{array}$} \\
\hline & Toplam & $\%$ Varyans & \% Yığılmalı & Toplam & $\%$ Varyans & \% Yığılmalı & Toplam & $\%$ Varyans & \% Yığılmalı \\
\hline 1 & 11.839 & 59.195 & 59.195 & 11.839 & 59.195 & 59.195 & 11.839 & 59.194 & 59.194 \\
\hline 2 & 1.162 & 5.812 & 65.007 & 1.162 & 5.812 & 65.007 & 1.163 & 5.813 & 65.007 \\
\hline 3 & .923 & 4.615 & 69.621 & & & & & & \\
\hline 4 & .701 & 3.505 & 73.126 & & & & & & \\
\hline 5 & .643 & 3.214 & 76.340 & & & & & & \\
\hline 6 & .546 & 2.731 & 79.071 & & & & & & \\
\hline 7 & .482 & 2.409 & 81.480 & & & & & & \\
\hline 8 & .428 & 2.138 & 83.618 & & & & & & \\
\hline 9 & .402 & 2.010 & 85.628 & & & & & & \\
\hline 10 & .377 & 1.884 & 87.512 & & & & & & \\
\hline 11 & .364 & 1.818 & 89.329 & & & & & & \\
\hline 12 & .343 & 1.716 & 91.045 & & & & & & \\
\hline 13 & .307 & 1.533 & 92.578 & & & & & & \\
\hline 14 & .274 & 1.368 & 93.946 & & & & & & \\
\hline 15 & .254 & 1.271 & 95.217 & & & & & & \\
\hline 16 & .250 & 1.251 & 96.468 & & & & & & \\
\hline 17 & .234 & 1.170 & 97.638 & & & & & & \\
\hline 18 & .208 & 1.041 & 98.680 & & & & & & \\
\hline 19 & .177 & .884 & 99.563 & & & & & & \\
\hline 20 & .087 & .437 & 100.000 & & & & & & \\
\hline \multicolumn{10}{|c|}{ Batı Müziği Derslerine Yönelik Maddeler } \\
\hline \multirow[t]{2}{*}{ Madde } & \multicolumn{3}{|c|}{ Başlangıç Özdeğerleri } & \multicolumn{3}{|c|}{ Kareli Yüklerin Ağırlıklı Toplamları } & \multicolumn{3}{|c|}{$\begin{array}{c}\text { Kareli Yüklerin } \\
\text { DöndürülmüșToplamları }\end{array}$} \\
\hline & Toplam & $\%$ Varyans & \% Yığılmalı & Toplam & $\%$ Varyans & \% Yığılmalı & Toplam & $\%$ Varyans & \% Yığılmalı \\
\hline 1 & 12.043 & 60.214 & 60.214 & 12.043 & 60.214 & 60.214 & 12.042 & 60.209 & 60.209 \\
\hline 2 & 1.068 & 5.342 & 65.557 & 1.068 & 5.342 & 65.557 & 1.070 & 5.348 & 65.557 \\
\hline 3 & .966 & 4.831 & 70.388 & & & & & & \\
\hline 4 & .638 & 3.191 & 73.579 & & & & & & \\
\hline 5 & .584 & 2.920 & 76.499 & & & & & & \\
\hline 6 & .530 & 2.651 & 79.150 & & & & & & \\
\hline 7 & .489 & 2.445 & 81.595 & & & & & & \\
\hline 8 & .433 & 2.167 & 83.763 & & & & & & \\
\hline 9 & .411 & 2.055 & 85.818 & & & & & & \\
\hline 10 & .402 & 2.011 & 87.829 & & & & & & \\
\hline 11 & .370 & 1.850 & 89.679 & & & & & & \\
\hline 12 & .334 & 1.671 & 91.350 & & & & & & \\
\hline 13 & .296 & 1.479 & 92.829 & & & & & & \\
\hline 14 & .277 & 1.383 & 94.212 & & & & & & \\
\hline 15 & .267 & 1.334 & 95.545 & & & & & & \\
\hline 16 & .225 & 1.124 & 96.669 & & & & & & \\
\hline 17 & .220 & 1.100 & 97.769 & & & & & & \\
\hline 18 & .186 & .929 & 98.698 & & & & & & \\
\hline 19 & .176 & .878 & 99.576 & & & & & & \\
\hline 20 & .085 & .424 & 100.000 & & & & & & \\
\hline
\end{tabular}


Türk ve Batı Müziği derslerine yönelik ölçeklerde yer alan maddelerin başlangıç özdeğerlerine bakıldığında, her iki ölçekte de birinci faktör yük değerinin yüksek çıktığı görülmektedir (YD $\left.\mathrm{YM}_{\mathrm{TM}}=11.839, \mathrm{YD}_{\mathrm{BM}}=12.043\right)$. Yine her iki ölçekte de birinci faktörün tek başına açıkladığı varyansın oldukça yüksek olduğu görülmektedir (Varyans ${ }_{\mathrm{TM}}=$ \%59.195, Varyans BM $_{1}=$ 60.214). Yüklerin döndürülmüş toplamlarına bakıldığında ise, yine her iki ölçekte de birinci faktörün tek başına açıkladığı varyansın oldukça yüksek olduğu görülmektedir (Varyans Varyans $_{\mathrm{BM}}=\%$ 60.209). Bunun anlamı maddelerin büyük çoğunluğunun tek faktörde birleştiği ve ölçeğin tek boyutlu bir yapıda olduğudur. Her iki ölçeğe ait faktör birikinti grafikleri Şekil 1 ve Şekil 2'de görülmektedir.

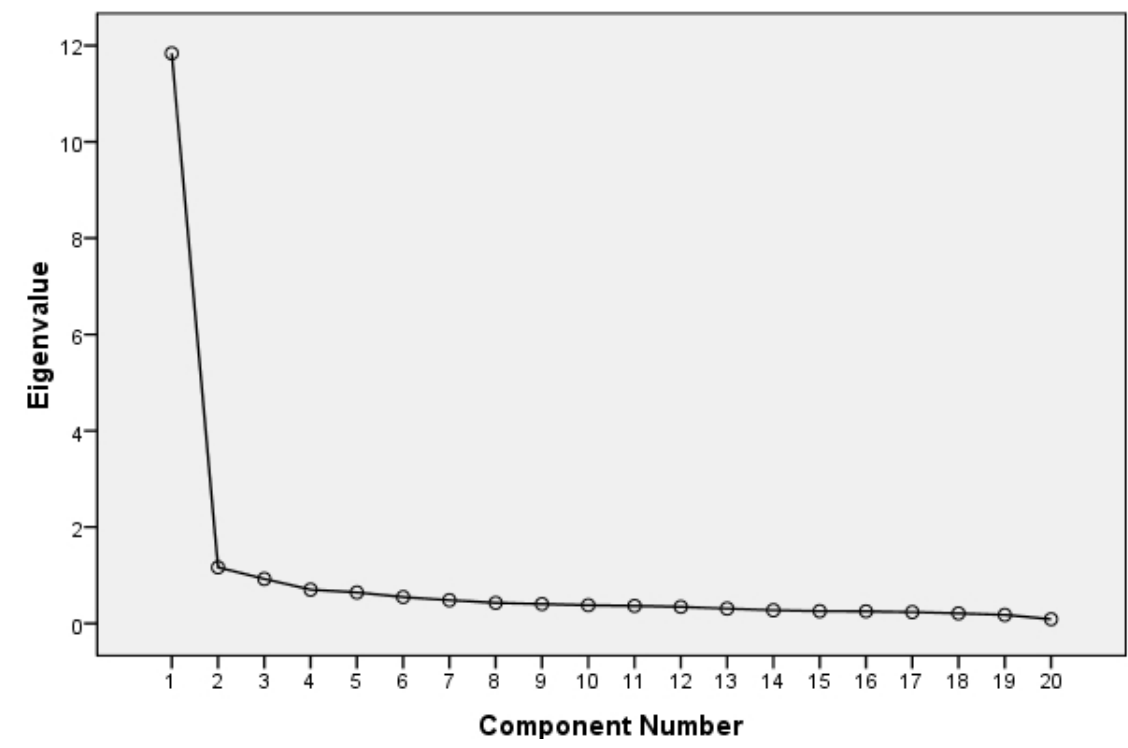

Şekil 1. Türk Müziği maddeleri birikinti grafiği

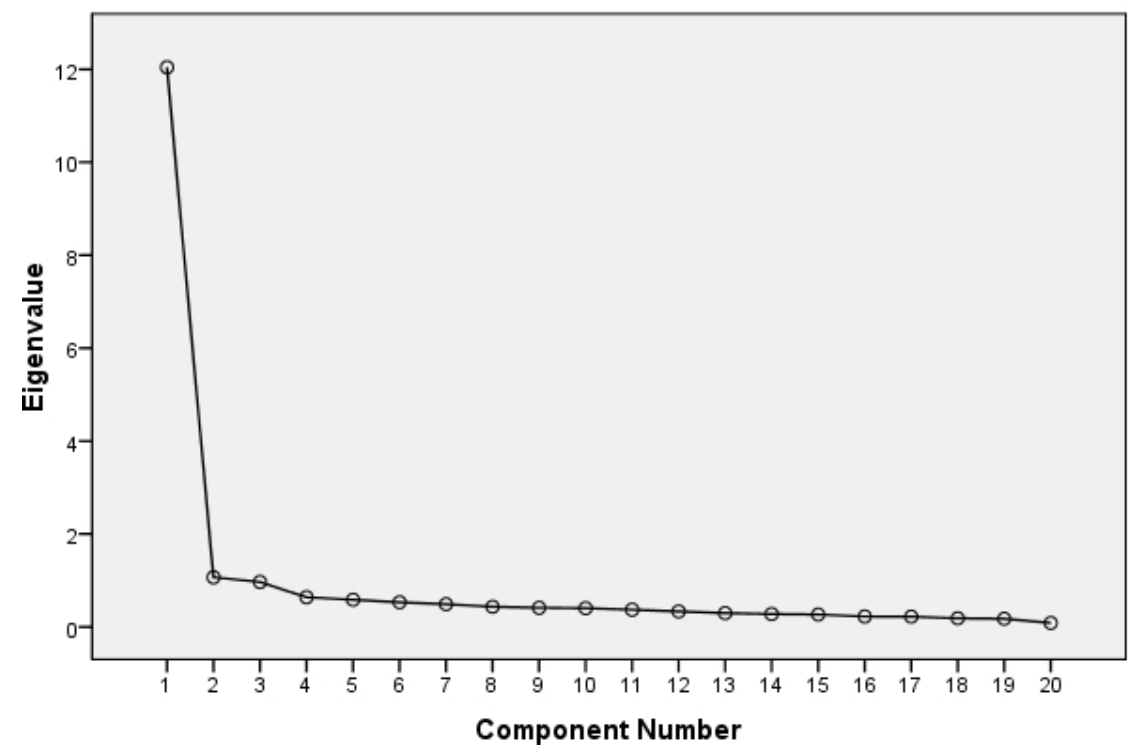

Şekil 2. Batı Müziği maddeleri birikinti grafiği

Şekil 1 ve Şekil 2'de Türk Müziği ve Batı Müziği derslerine yönelik tutum ölçeği maddelerinin birikinti grafiklerine bakıldığında, ilk faktörden sonra büyük bir düşüş görülmekte ve sonraki faktörler ise paralel bir görünüm sergilemektedir. Buna bağlı olarak ilk faktörden sonraki faktörlerin varyansa olan katkılarının çok düşük ve birbirine yakın olduğu söylenebilir.

Faktör yük değerlerinin daha net ortaya koyulabilmesi için, Türk Müziği ve Batı Müziği derslerine yönelik tutum ölçeği madde matriksleri ve döndürülmüş madde matriksleri tespit edilmiştir. Madde matriksleri ve döndürülmüş madde matriksleri Tablo 7'de görülmektedir. 
Merve Karakuş, Koray Çelenk

GSL Müzik Bölümleri Müfredatındaki Türk ve Batı Müziği Derslerine Yönelik Tutum Ölçeği Geliştirme Çalışması

GSED, 2020; Cilt: 26, Sayı: Müzik Özel Sayıs1: 327-337 - DOI: 10.32547/ataunigsed.701526

Tablo 7

Türk Müziği ve Batı Müziği ölçekleri madde ve döndürülmüş madde matriksleri

\begin{tabular}{|c|c|c|c|c|c|c|c|c|c|c|c|}
\hline \multicolumn{6}{|c|}{ Türk Müziği Maddeleri } & \multicolumn{6}{|c|}{ Batı Müziği Maddeleri } \\
\hline \multicolumn{3}{|c|}{ Madde Matriksi } & \multicolumn{3}{|c|}{ Döndürülmüş Madde Matriksi } & \multicolumn{3}{|c|}{ Madde Matriksi } & \multicolumn{3}{|c|}{ Döndürülmüş Madde Matriksi } \\
\hline \multirow{2}{*}{ Maddeler } & \multicolumn{2}{|c|}{ Faktörler } & \multirow{2}{*}{ Maddeler } & \multicolumn{2}{|c|}{ Faktörler } & \multirow[t]{2}{*}{ Maddeler } & \multicolumn{2}{|c|}{ Faktörler } & \multirow[t]{2}{*}{ Maddeler } & \multicolumn{2}{|c|}{ Faktörler } \\
\hline & 1 & 2 & & 1 & 2 & & 1 & 2 & & 1 & 2 \\
\hline 2 & .905 & & 2 & .906 & & 2 & .876 & & 2 & .874 & \\
\hline 1 & .886 & & 1 & .886 & & 1 & .874 & & 1 & .873 & \\
\hline 16 & .864 & & 16 & .864 & & 16 & .859 & & 16 & .858 & \\
\hline 5 & .852 & & 5 & .853 & & 5 & .828 & & 5 & .825 & \\
\hline 10 & .850 & & 10 & .850 & & 10 & .818 & & 10 & .816 & \\
\hline 4 & .825 & & 4 & .826 & & 20 & .804 & & 20 & .806 & \\
\hline 9 & .821 & & 9 & .821 & & 9 & .795 & & 19 & .796 & \\
\hline 3 & .817 & & 3 & .816 & & 19 & .794 & & 9 & .795 & \\
\hline 20 & .796 & & 20 & .794 & & 4 & .789 & -.340 & 11 & .789 & \\
\hline 19 & .779 & .307 & 19 & .780 & -.304 & 11 & .787 & & 4 & .785 & .347 \\
\hline 11 & .761 & & 11 & .760 & & 3 & .778 & & 3 & .778 & \\
\hline 12 & .743 & & 12 & .742 & & 17 & .770 & .401 & 17 & .774 & -.393 \\
\hline 15 & .740 & -.349 & 15 & .738 & .353 & 12 & .753 & .331 & 12 & .757 & -.323 \\
\hline 17 & .737 & -.313 & 17 & .736 & .317 & 15 & .742 & .301 & 15 & .744 & \\
\hline 7 & .713 & & 7 & .714 & & 13 & .728 & & 13 & .729 & \\
\hline 14 & .694 & & 14 & .695 & & 14 & .727 & & 14 & .724 & \\
\hline 6 & .683 & .394 & 6 & .685 & -.391 & 7 & .722 & -.407 & 7 & .717 & .414 \\
\hline 18 & .672 & .330 & 18 & .673 & -.327 & 6 & .713 & & 6 & .713 & \\
\hline 13 & .571 & .407 & 13 & .573 & -.404 & 18 & .667 & & 18 & 669 & \\
\hline 8 & .566 & -.411 & 8 & .564 & .414 & 8 & .648 & & 8 & .648 & \\
\hline
\end{tabular}

Tablo 7 incelendiğinde hem Türk Müziği derslerine yönelik tutum ölçeğinde, hem de Batı Müziği derslerine yönelik tutum ölçeğinde tüm maddelerde birinci faktör değerlerinin daha yüksek olduğu ve tüm maddeleri en yüksek düzeyde açıklayan faktörün birinci faktör olduğu görülmektedir. Elde edilen tüm bilgiler doğrultusunda Türk ve Batı Müziği derslerine yönelik geliştirilen tutum ölçeklerinin yap1 geçerliğini sağladığı ve tutumu ölçen tek faktörlü bir yapıda olduğu belirlenmiştir.

\section{3. Ölçeklerin güvenirliklerine yönelik bulgular}

Kapsam ve yapı geçerliğini sağlayan Türk ve Batı Müziği derslerine yönelik tutum ölçeklerinin güvenirliğini test etmek üzere Cronbach's Alpha güvenirlik testi uygulanmıştır. Tablo 8'de Cronbach's Alpha güvenirlik testi sonuçları görülmektedir.

Tablo 8

Türk ve Batı Müziği ölçekleri Cronbach’s Alpha güvenirlik testi sonuçları

\begin{tabular}{|c|c|c|c|}
\hline \multicolumn{2}{|c|}{ Türk Müziği } & \multicolumn{2}{|c|}{ Batı Müziği } \\
\hline Maddeler & Cronbach's Alpha & Maddeler & Cronbach's Alpha \\
\hline 1 & .959 & 1 & .961 \\
\hline 2 & .959 & 2 & .961 \\
\hline 3 & .960 & 3 & .963 \\
\hline 4 & .960 & 4 & .963 \\
\hline 5 & .959 & 5 & .962 \\
\hline 6 & .961 & 6 & .964 \\
\hline 7 & .961 & 7 & .963 \\
\hline 8 & .963 & 8 & .964 \\
\hline 9 & .960 & 9 & .962 \\
\hline 10 & .959 & 10 & .962 \\
\hline 11 & .961 & 11 & .963 \\
\hline 12 & .961 & 12 & .963 \\
\hline 13 & .963 & 13 & .963 \\
\hline 14 & .961 & 14 & .963 \\
\hline 15 & .961 & 15 & .963 \\
\hline 16 & .959 & 16 & .962 \\
\hline 17 & .961 & 17 & .963 \\
\hline 18 & .962 & 18 & .964 \\
\hline 19 & .960 & 19 & .963 \\
\hline 20 & .960 & 20 & .962 \\
\hline Ölçek Toplam Güvenirlik & .962 & Ölçek Toplam Güvenirlik & .965 \\
\hline
\end{tabular}


Tablo 8 incelendiğinde Türk ve Batı Müziği derslerine yönelik geliştirilen ölçeklerin hem madde bazında, hem de ölçek madde toplamı bazında güvenirliği sağladığı ve her iki ölçeğin de yüksek derecede güvenilir olduğu görülmektedir $(\mathrm{TM}(\alpha)=0.962, \mathrm{BM}(\alpha)=0.965)$.

Elde edilen tüm bulgular doğrultusunda, Türk Müziği ve Batı Müziği derslerine yönelik 5'li Likert tipinde geliştirilen ve geçerliği ve güvenirliği test edilen tutum ölçeklerinin, Güzel Sanatlar Liselerinde Türk Müziği ve Batı Müziği derslerine yönelik öğrenci tutumlarının belirlenmesinde kullanılabilecek geçerli ve güvenilir birer araç olduğu söylenebilir.

\section{Sonuç}

Araştırmada elde edilen bulgular doğrultusunda ulaşılan sonuçlar aşağıdaki gibidir.

- Uzman görüşleri doğrultusunda, KGO değerleri hesaplanan 26 maddelik ölçeklerden KGO oranı negatif olan 6'şar madde çıkarılmıştır. KGO, KGÖ ve KGİ oranlarına göre ölçeklerde kalan 20 maddenin kapsam geçerliğini sağladığı sonucuna ulaşılmıştır.

- Kapsam geçerliği sağlanan ölçeklerin yapı geçerliğini test etmek amacı ile faktör analizi uygulanmış ve ölçeklerin tek faktör altında toplandığı ve tutumu ölçen tek boyutlu bir yapıda oldukları sonucuna ulaşılmıştır. Ölçeklere ilişkin açıklanan varyansların ise, Türk Müziği derslerine yönelik ölçek için Varyans ${ }_{\mathrm{TM}}=\% 59.195$ ve Batı Müziği derslerine yönelik ölçek için Varyans BM $=\% 60.214$ oranla belirlenen faktörün ölçeklerdeki maddeleri yüksek oranda açıkladığı ve ölçeğin yapı geçerliğini sağladığı sonucuna ulaşılmıştır.

- Ölçeklerin güvenirliğini test etmek amacı ile uygulanan Cronbach's Alpha güvenirlik testi sonucunda, madde ilişki düzeylerinin yüksek olduğu ve ölçeklerin güvenirliğinin yüksek derecede olduğu $(\mathrm{TM}(\alpha)=0.962$, BM $(\alpha)=0.965)$ sonucuna ulaşılmıştır.

- Elde edilen bulgular doğrultusunda geliştirilen ölçeklerin, Güzel Sanatlar Liselerinde Türk Müziği ve Batı Müziği derslerine yönelik öğrenci tutumlarının belirlenmesinde kullanılabilecek geçerli ve güvenilir birer araç olduğu belirlenmiştir.

Araştırma sonuçları literatürdeki ilgili araştırmalar ile birlikte değerlendirildiğinde, yapılan çalışmaların ilköğretim, ortaöğretim ve lise düzeylerindeki müfredatlarda yer alan müzik dersine, Mesleki Müzik Eğitimi içinde var olan alan derslerine, öğretmenlik mesleğine, çalgıya, sınıf ve okul öncesi eğitiminde müzik öğretimi dersine ve müzik algılarına yönelik tutum ölçeği geliştirme ya da tutumları belirlemeye yönelik çalışmalar olduğu görülmüştür. Araştırmaya konu olan Güzel Sanatlar Liselerine yönelik yapılan tutum çalışmalarına bakıldığında ise, (Bakıner, 2004), (Civan, 2006), (Kılınçer, 2009), (İnan, 2010), (Özer, 2010) ve (Tan, 2016)'a ait çalışmalara rastlanmaktadır. Bu çalışmalarda ele alınan konuların ise, müzik öğretmenliği, müziksel işitme dersi ve piyano dersine yönelik tutumların belirlenmesi ve tutumların belli değişkenlere göre karşılaştırılarak tutumlar üzerindeki etkilerinin ortaya koyulduğu çalışmalar olduğu görülmüştür. Güzel Sanatlar Liselerindeki Türk ve Batı Müziği derslerine yönelik tutumlar ile ilgili bir çalışmaya rastlanmamıştır.

Araştırma kapsamında Güzel Sanatlar Liseleri müfredatındaki Türk Müziği ve Batı Müziği derslerine yönelik öğrenci tutumlarını belirlemek için geliştirilen tutum ölçeklerinin, öğrencilerin Türk Müziği ve Batı Müziği eğilimlerinin ortaya koyulması, ileride bu branşı meslek olarak seçecek kişilerin üniversitelerde tercih edecekleri bölümler açısından farkındalıklarının ortaya çıkarılması ve alanda yapılan diğer çalıșmalar ile müzik eğitiminin sorunlarına 1şık tutması açısından katkı sağlayacağı; ayrıca, GSL ders programlarındaki derslere yönelik olarak düzenli şekilde tutum belirleme çalışmalarının yapılmasının, olumsuz tutum sergilenen derslerin belirlenmesinde ve ileride oluşturulacak programların daha verimli ve sağlıklı olarak oluşturulmasında etkili olacağ düşünülmektedir.

\section{Kaynakça}

Bakıner, A. (2004). Anadolu Güzel Sanatlar Liseleri ve Özel Güzel Sanatlar Liselerindeki müzik ögrencilerinin müzik ön yaşantıları, müzik yetenekleri, müziğe yönelik tutumları ve eğitim programlarını değerlendirme özelliklerinin karşılaştırılması (Yüksek lisans tezi). YÖK Tez veri tabanından erişildi. (Tez No. 148825)

Berberoğlu, G. (1990). Kimyaya ilişkin tutumların ölçülmesi. Eğitim ve Bilim, 14(76), 16-27.

Büyüköztürk, Ş. (2011). Sosyal bilimler için veri analizi el kitabı istatistik, araştırma deseni, SPSS uygulamaları ve yorum. Ankara: Pegem Akademi.

Canakay, E. U. (2006). Müzik teorisi dersine ilişkin tutum ölçeği geliştirme. Ulusal Müzik Eğitimi Sempozyumu'nda sunulan bildiri, Denizli: Pamukkale Üniversitesi.

Civan, K. (2006). Anadolu Güzel Sanatlar Liselerindeki müzik bölümü öğrencilerinin müzik öğretmenliği mesleğine yönelik tutumları (Yüksek lisans tezi). YÖK Tez veri tabanından erişildi. (Tez No. 189792) 
Çelenk, K. (2019). Mesleki Müzik Eğitiminde yaylı çalgılar için performans ölçeği geliştirme çalışması. M. B. Minaz (Ed.), Eğitim bilimleri alanında yeni ufuklar (s. 113-134) içinde. Ankara: Gece Kitaplığı.

Çelenk, K., \& Özşen, B. (2018). Yaylı çalgı eğitiminde öğrenci performansının ölçülmesi ve değerlendirilmesi. M. Keha \& Z. Alimgereyev (Ed.), IV. Uluslararası Mesleki ve Teknik Bilimler Kongresi Tam Metin Kitabı: Vol. 1 (s. 491-508) içinde. Gaziantep: İksad Press.

İnan, E. (2010). Anadolu Güzel Sanatlar Lisesi Müzik Bölümü öğrencilerinin müziksel işitme okuma yazma dersi ile ilgili tutumlarının bazı değişkenlere göre incelenmesi (Yüksek lisans tezi). YÖK Tez veri tabanından erişildi. (Tez No. 264096)

İnceoğlu, M. (2010). Tutum algı iletişim. İstanbul: Beykent Üniversitesi Yayınları.

Karasar, N. (2007). Bilimsel araştırma yöntemi. Ankara: Nobel Yayınevi.

Kılınçer, Ö. (2009). Anadolu Güzel Sanatlar Liseleri Müzik Bölümü öğrencilerinin piyano dersine yönelik tutumlarının incelenmesi (Yüksek lisans tezi). YÖK Tez veri tabanından erişildi. (Tez No. 240521)

Lawshe, C. H. (1975). A quantitative approach to content validity. Personnel Psychology, 28(4), 563-575. Doi: https://doi.org/10.1111/j.1744-6570.1975.tb01393.x

Milli Eğitim Bakanlığı. (2018). 2018-2019 ĕgitim ve ögretim yılı Güzel Sanatlar Liseleri istatistikleri (Rapor). Milli Eğitim Bakanlığı Ortaöğretim Genel Müdürlüğü web sayfasından erişildi: http://ogm.meb.gov.tr/meb_iys_dosyalar/2018_09/19185304_GYzel_Sanatlar_Liseleri.pdf

Oskamp, S. (1977). Attitudes and opinions. Englewood Cliffs, New Jersey: Prentice-Hall.

Özdamar, K. (2011). Paket programlar ile istatistiksel veri analizi. Eskişehir: Kaan Kitapevi.

Özer, Z. (2010). Bursa Zeki Müren Güzel Sanatlar ve Spor Lisesi Müzik Bölümü piyano dersinde kullanılan anlamlandırma stratejilerinin ögrencilerin öğrenme düzeylerine ve tutumlarına etkisi (Yüksek lisans tezi). YÖK Tez veri tabanından erişildi. (Tez No. 273226)

Saracaloğlu, A. S. (1996). Ortaöğretim kurumlarında sosyal bilimler öğretimi. E.Ü. Edebiyat Fakültesi Coğrafya Meslek Haftası Bildiri Özetleri, İzmir.

Şen, Y., \& Şentürk, N. (2015). Geleneksel Türk Müziği derslerine ilişkin tutum ölçeği geliştirme süreci. Karadeniz Sosyal Bilimler Dergisi, 1(Özel Sayı), 261-282. Erişim adresi: https://dergipark.org.tr/tr/download/articlefile/149854

Tan, H. (2016). Güzel Sanatlar Lisesi öğrencilerinin müzik öğretmenliği mesleğine yönelik tutumlarının incelenmesi (Yüksek lisans tezi). YÖK Tez veri tabanından erişildi. (Tez No. 430496)

Tavşancıl, E. (2006). Tutumların ölçülmesi ve SPSS ile veri analizi. Ankara: Nobel Yayınevi.

Turan, İ., Şimşek, Ü., \& Aslan, H. (2015). Eğitim araştırmalarında Likert ölçeği ve Likert tipi soruların kullanımı ve analizi. Sakarya Üniversitesi Eğitim Fakültesi Dergisi, 30, 186-203. Erişim adresi: https://dergipark.org.tr/tr/download/article-file/115904

Veneziano L., \& Hooper J. (1997). A method for quantifying content validity of health-related questionnaires. American Journal of Health Behavior, 21(1), 67-70. Erişim adresi: https://www.scienceopen.com/document?vid=8254f3c9-3a49-4e44-b430-1643adfc84ae

Yeşilyurt, S., \& Çapraz, C. (2018). Ölçek geliştirme çalışmalarında kullanılan kapsam geçerliği için bir yol haritas1. Erzincan Üniversitesi Eğitim Fakültesi Dergisi, 20(1), 251-264. Doi: 10.17556/erziefd.297741 


\section{EKLER}

\section{EK 1. Türk Müziği Derslerine Yönelik Tutum Ölçeği}

\begin{tabular}{|c|c|c|c|c|c|}
\hline $\begin{array}{l}\text { Aşağıdaki ifadeleri okuduktan sonra, yanda verilen dereceleme ölçeğine göre size en } \\
\text { uygun seçeneği }(X) \text { işareti koyarak işaretleyiniz. }\end{array}$ & 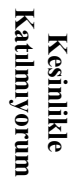 & 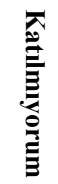 & 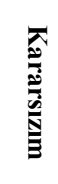 & 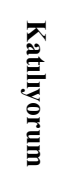 & 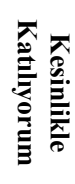 \\
\hline 1. Türk Müziği derslerini severim & $\square$ & $\square$ & $\square$ & $\square$ & $\square$ \\
\hline 2. Türk Müziği derslerini ilgi çekici bulurum & $\square$ & $\square$ & $\square$ & $\square$ & $\square$ \\
\hline 3. Zorunlu olmasaydım Türk Müziği derslerine katılmak istemezdim & $\square$ & $\square$ & $\square$ & $\square$ & $\square$ \\
\hline 4. Boş zamanlarımda Türk Müziği ile ilgilenirim & $\square$ & $\square$ & $\square$ & $\square$ & $\square$ \\
\hline 5. Türk Müziği derslerinde verilen eserleri zevkle çalışırım & $\square$ & $\square$ & $\square$ & $\square$ & $\square$ \\
\hline 6. Türk Müziği derslerinde öğrendiklerimin diğer derslere de yararı olacağını düşünürüm & $\square$ & $\square$ & $\square$ & $\square$ & $\square$ \\
\hline 7. Türk Müziği dersleri ile ilgili araştırma yapmaktan hoşlanırım & $\square$ & $\square$ & $\square$ & $\square$ & $\square$ \\
\hline 8. Türk Müziği derslerinde tüm ilgimi derse veremem & $\square$ & $\square$ & $\square$ & $\square$ & $\square$ \\
\hline 9. Türk Müziği dersleriyle ilgili etkinliklere severek katılırım & $\square$ & $\square$ & $\square$ & $\square$ & $\square$ \\
\hline 10. Türk Müziği ders saatlerinin daha çok olmasını isterim & $\square$ & $\square$ & $\square$ & $\square$ & $\square$ \\
\hline 11. Türk Müziği derslerini ilgi alanıma uzak bulurum & $\square$ & $\square$ & $\square$ & $\square$ & $\square$ \\
\hline 12. Mezuniyetten sonra Türk Müziği ile ilgili hiçbir şey duymak istemem & $\square$ & $\square$ & $\square$ & $\square$ & $\square$ \\
\hline 13. Türk Müziği derslerinin beni kültürel anlamda geliştirdiğine inanırım & $\square$ & $\square$ & $\square$ & $\square$ & $\square$ \\
\hline 14. Türk Müziği derslerine diğer derslerden daha çok önem veririm & $\square$ & $\square$ & $\square$ & $\square$ & $\square$ \\
\hline 15. Türk Müziği derslerine sadece sınıf geçmek için çalışırım & $\square$ & $\square$ & $\square$ & $\square$ & $\square$ \\
\hline 16. Türk Müziği derslerinde öğrendiğim eserleri icra etmekten hoşlanırım & $\square$ & $\square$ & $\square$ & $\square$ & $\square$ \\
\hline 17. Türk Müziği derslerinin zaman kaybı olduğunu düşünürüm & $\square$ & $\square$ & $\square$ & $\square$ & $\square$ \\
\hline 18. Türk Müziği dersleri olmadan alınan eğitimin yetersiz olacağını düşünürüm & $\square$ & $\square$ & $\square$ & $\square$ & $\square$ \\
\hline $\begin{array}{l}\text { 19. Aldığım Türk Müziği derslerinin üniversitedeki derslerde kolaylık sağlayacağına } \\
\text { inanırım }\end{array}$ & $\square$ & $\square$ & $\square$ & $\square$ & $\square$ \\
\hline 20. Türk Müziği derslerindeki eserleri dinlemekten sıkılırım & $\square$ & $\square$ & $\square$ & $\square$ & $\square$ \\
\hline
\end{tabular}

\section{EK 2. Batı Müziği Derslerine Yönelik Tutum Ölçeği}

Aşağıdaki ifadeleri okuduktan sonra, yanda verilen dereceleme ölçeğine göre size en uygun seçeneği $(X)$ işareti koyarak işaretleyiniz.

1. Batı Müziği derslerini severim

2. Batı Müziği derslerini ilgi çekici bulurum

3. Zorunlu olmasaydım Batı Müziği derslerine katılmak istemezdim

4. Boş zamanlarımda Batı Müziği ile ilgilenirim

5. Batı Müziği derslerinde verilen eserleri zevkle çalıșırım

6. Batı Müziği derslerinde öğrendiklerimin diğer derslere de yararı olacağını düşünürüm

7. Batı Müziği dersleri ile ilgili araştırma yapmaktan hoşlanırım

8. Batı Müziği derslerinde tüm ilgimi derse veremem

9. Batı Müziği dersleriyle ilgili etkinliklere severek katılırım

10. Batı Müziği ders saatlerinin daha çok olmasını isterim

11. Batı Müziği derslerini ilgi alanıma uzak bulurum

12. Mezuniyetten sonra Batı Müziği ile ilgili hiçbir şey duymak istemem

13. Batı Müziği derslerinin beni kültürel anlamda geliştirdiğine inanırım

14. Batı Müziği derslerine diğer derslerden daha çok önem veririm

15. Batı Müziği derslerine sadece sınıf geçmek için çalışırım

16. Batı Müziŏi derslerinde öğrendiğim eserleri icra etmekten hoslanırım

17. Batı Müziği derslerinin zaman kaybı olduğunu düşünürüm

18. Batı Müziği dersleri olmadan alınan eğitimin yetersiz olacağını düșünürüm

19. Aldığım Batı Müziği derslerinin üniversitedeki derslerde kolaylık sağlayacağına inanırım

20. Batı Müziği derslerindeki eserleri dinlemekten sıkılırım 